\title{
Comparison between the effect of pentosan polysulphate heparin and antithrombin III injections in antithrombin III deficient patients
}

Citation for published version (APA):

Fischer, A. M., Dautzenberg, M. D., Aurousseau, M. H., Beguin, S., Goudemand, J., \& Hemker, H. C. (1985). Comparison between the effect of pentosan polysulphate heparin and antithrombin III injections in antithrombin III deficient patients. Thrombosis Research, 37(2), 295-307. https://doi.org/10.1016/00493848(85)90018-0

Document status and date:

Published: 01/01/1985

DOI:

10.1016/0049-3848(85)90018-0

Document Version:

Publisher's PDF, also known as Version of record

Please check the document version of this publication:

- A submitted manuscript is the version of the article upon submission and before peer-review. There can be important differences between the submitted version and the official published version of record.

People interested in the research are advised to contact the author for the final version of the publication, or visit the DOI to the publisher's website.

- The final author version and the galley proof are versions of the publication after peer review.

- The final published version features the final layout of the paper including the volume, issue and page numbers.

Link to publication

\footnotetext{
General rights rights.

- You may freely distribute the URL identifying the publication in the public portal. please follow below link for the End User Agreement:

www.umlib.nl/taverne-license

Take down policy

If you believe that this document breaches copyright please contact us at:

repository@maastrichtuniversity.nl

providing details and we will investigate your claim.
}

Copyright and moral rights for the publications made accessible in the public portal are retained by the authors and/or other copyright owners and it is a condition of accessing publications that users recognise and abide by the legal requirements associated with these

- Users may download and print one copy of any publication from the public portal for the purpose of private study or research.

- You may not further distribute the material or use it for any profit-making activity or commercial gain

If the publication is distributed under the terms of Article $25 \mathrm{fa}$ of the Dutch Copyright Act, indicated by the "Taverne" license above, 
THROMBOSIS RESEARCH 37; 295-307, 1985

$0049-3848 / 85 \$ 3.00+.00$ Printed in the USA.

Copyright (c) 1985 Pergamon Press Ltd. A11 rights reserved.

\section{COMPARISON BETWEEN THE EFFECT OF PENTOSAN POLYSULPHATE HEPARIN AND ANTITHROMBIN III INJECTIONS IN ANTITHROMBIN III DEFICIENT PATIENTS}

A.M. Fischer ${ }^{1}$, M.D. Dautzenberg ${ }^{1}$, M.H. Aurousseau ${ }^{2}$, S. Béguin ${ }^{1}$, J. Goudemand ${ }^{3}$ and H.C. Hemker ${ }^{4}$.

1. CHU Necker-Enfants Malades, 75730 Paris cédex 15. 2. Hôpital Jean Verdier, 93140 Bondy. 3. CHR de Lille, France. 4. Department of Biochemistry, Limburg University, 6200 MD, Maastricht, The Netherlands.

(Received 22.4.1984; Accepted in revísed form 20.10.1984 by Editor C.A. Bouvier)

\section{ABSTRACT}

Pentosan polysulphate is an heparin analogue which acts via an antithrombin III (AT III) independent pathway. We compared the effect of this drug to that of heparin and AT III infusions in AT III deficient patients. Four patients with AT III congenital deficiency received on three different occasions : (i) an infusion of human AT III concentrate $(20 \mathrm{U} / \mathrm{kg}$ or $40 \mathrm{U} / \mathrm{kg})$, (ii) an intramuscular injection of pentosan polysulphate $(2 \mathrm{mg} / \mathrm{kg})$, (iii) a subcutaneous calcium heparin injection $(100 \mathrm{U} / \mathrm{kg})$. AT III infusion inhibits the excessive thrombin generation (46 \% of inhibition) observed in the plasma of AT III deficient patients during at least 12 hours, but does not modify the factor Xa formation. On the contrary, pentosan polysulphate has a marked effect on both thrombin $162 \%$ of inhibition) and factor $\mathrm{Xa}$ generation (57\% of inhibition) still present 8 hours after injection. Heparin injection has the same effect, more prolonged, as pentosan polysulphate on thrombin generation but is not so effective on impairing factor $\mathrm{Xa}$ generation (27\% of inhibition). The marked effect of pentosan polysulphate on thrombin and factor Xa generation in these patients is due to its AT III independent mechanism of action.

\section{INTRODUCTION}

Patients with a congenital AT III deficiency show a general tendency to thrombo-embolism (1). To prevent accidents,

Key words : AT III concentrate, heparin, pentosan polysulphate, AT III deficiency. 
long term prophylaxis with antagonists of vitamin $K$ is considered to be at this moment the treatment of choice (2). A well controlled oral anticoagulation will as a rule ensure a reasonable prophylaxis but in some instances may be difficult or impossible. Surgical interventions, early and late pregnancy and other counter-indications such as liver disease or intestinal malabsorption may prevent its use. In these cases, patients can be treated with AT III concentrate infusion and/or heparin.

Here we propose the administration of pentosan polysulphate (Hemoclar) as a new form of treatment. Pentosan polysulphate is an heparin analogue widely used in Germany and France as an antithrombotic and antilipaemic drug. It has a weak anticoagulant activity compared to heparin when measured by Activated Partial Thromboplastin Time (A.P.T.T.) assay $(3,4)$, but inhibits markedly the thrombin and Xa generations by an AT III independent mechanism (5). We tested the efficacy of this drug in AT III deficient patients compared to AT III infusion and heparin injection (Calciparine). The only observed abnormality of haemostasis in AT III deficient patients is an increase of thrombin generation $(6,7)$ while the intrinsic generation of factor $X a$ is normal.

However to prevent thrombosis in these patients with a high risk of thrombo-embolism, we do not just try to decrease their excessive thrombin formation but also to act earlier in the coagulation cascade, by impairing the factor Xa formation. So we tested the effect of each treatment by monitoring the appearance of thrombin and activated factor $X$ in blood samples from the patients at regular intervals after administration of the drugs.

\section{MATERIAL AND METHODS}

In vivo studies :

Four patients (three women, one man) with a congenital AT III deficiency (type I), on three different occasions, received (i) an intramuscular injection $(2 \mathrm{mg} / \mathrm{kg})$ of pentosan polysulphate (Hemoclar, Laboratoire Clin-Midy, Paris, France) ; (ii) an infusion of purified human AT III concentrate from Centre Regional de Transfusion Sanguine, Lille, France : $40 \mathrm{U} / \mathrm{kg}$ for three of them and $20 \mathrm{U} / \mathrm{kg}$ for the last one, this amount being his usual prophylaxis ; this patient was nevertheless included in the protocol because the effect of AT III infusion on factor $\mathrm{Xa}$ and thrombin generation was similar whatever the dose used $(40 \mathrm{U} / \mathrm{kg}$ or $20 \mathrm{U} / \mathrm{kg})$ during the first 12 hours after injection; (iii) a subcutaneous calcium heparin injection (100 U/kg) (Calciparine, Laboratoire Choay, Paris, France) in three patients only.

Venous blood samples were obtained (i) before (TO) and at $1(\mathrm{~T} 1), 4(\mathrm{~T} 4), 6(\mathrm{~T} 6), 8(\mathrm{~T})$ ) and 12 hours $(\mathrm{T} 12)$ after pentosan polysulphate injection and mixed with $0.13 \mathrm{M}$ trisodium citrate at a ratio of 1 part citrate to 9 parts blood; (ii) at To, T2, T4, T6, T8 and T12 after heparin injection; (iii) at To, 
T2, T6 and T12 after AT III infusion; the time of the first samples after heparin (T2) and pentosan polysulphate (T1) injections were chosen, according to the peak effect observed in a previous study (8). Samples were immediately centrifuged, first at $+12^{\circ} \mathrm{C}$ during 10 minutes at $2500 \mathrm{~g}$, and then at $+4^{\circ} \mathrm{C}$ during 30 minutes at $5000 \mathrm{~g}$. The plasma was then stored at $-80^{\circ} \mathrm{C}$ in plastic tubes until tested.

Informed consent of the patients was obtained.

In vitro studies :

In all the samples, the following tests were performed : Kaolin Cephalin Clotting Time, prothrombin time, factor Xa generation test, thrombin generation test, plasmatic AT III determination.

The Kaolin Cephalin Clotting Time (K.C.C.T.) was carried out using human brain cephalin as described previously (9).

Prothrombin Time (P.T.) : to $0.1 \mathrm{ml}$ of test plasma were added $0.2 \mathrm{ml}$ of Neoplastin (Laboratoire Stago, France) and the clotting times recorded.

Intrinsic generation of factor $\mathrm{Xa}$ in plasma : 1 vol. of Reptilase (Laboratoire Stago, France) defibrinated ( $20 \mu 1$ of Reptilase/ml plasma) platelet poor plasma was added to 1 vol. of Cephotest (cephalin plus ellagic acid, Nyegaard and Co, Oslo, Norway) and $1 \mathrm{vol}$. of $25 \mathrm{mM} \mathrm{CaCl}_{2}$. The mixture was incubated at $37^{\circ} \mathrm{C}$ in a plastic tube. At time intervals, the amount of factor Xa generated was determined by adding an aliquot of the incubation mixture to a solution of chromogenic substrate, S-2222 (Kabi Diagnostica, Sweden), as described previously (5). The absorbance was recorded at $405 \mathrm{~nm}$. The initial rate ( $\triangle \mathrm{OD} / \mathrm{minute})$ was proportional to the amount of factor Xa generated.

Thrombin generation test : 1 vol. of undefibrinated platelet poor plasma and 1 vol. of human brain cephalin diluted in $25 \mathrm{mM} \mathrm{CaCl} 2$ were mixed in a glass test tube at $37^{\circ} \mathrm{C}$. The amount of thrombin generated was measured at intervals by adding $0.1 \mathrm{ml}$ aliquots of the incubation mixture to $0.4 \mathrm{ml}$ of purified human fibrinogen (2 $\mathrm{g} / 1$ ) prepared as previously described (10). Results were expressed in thrombin N.I.H. units using a calibration curve obtained with serial dilutions of a standard thrombin solution.

The amount of thrombin and factor Xa generated were quantified as following: the peak value (hx $; x=$ time in hours after drug injection) of each generation curve was determined, as well as the difference between the peak value obtained with the blood sample taken before administration of the drug ho and hx (figure 1). At each time (x) after injection, the mean of the four differences (ho - hx) obtained for the four patients was calculated. For each drug and at each time the ratio between the 
mean of these four differences and the mean of the four values of ho was used to calculate the percentage of inhibition of thrombin and factor Xa formation.

AT III determinations : AT III heparin cofactor activity was measured with a chromogenic substrate, Chromozym TH (Laboratoire Stago, France) according to Abildgaard (11) and AT III antigen level measured by Mancini radial immunodiffusion method using plates purchased from Behringwerke, Marburg, West Germany (M-Partigen(B)). The AT III levels were expressed as a percentage of the mean value of 15 normal plasma.

Crossed immunoelectrophoresis : crossed immunoelectrophoCrossed immunoelectrophor the two dimensional immunoelec-
resis of AT III was performed by the trophoresis technique of Laurell (12) modified by Sas (13) in
troph the absence or in the presence of heparin in the first electrophoresis $(220$ units heparin/ml buffer, 79 units heparin/ml agarose) and using $2 \%$ rabbit anti-AT III antiserum (Behringwerke, Marburg, West Germany) in the second electrophoresis.

\section{RESULTS}

Characteristics of the patients are summarized in table 1.

Characteristics of the AT III deficiency of the family 1 have been published previously (14). Five members of this family with the same AT III level have suffered from severe thrombo-embolic episodes; they were not included in the study because they had a long term prophylaxis with antagonists of vitamin $\mathrm{K}$.

TABLE 1

CHARACTERISTICS OF THE PATIENTS

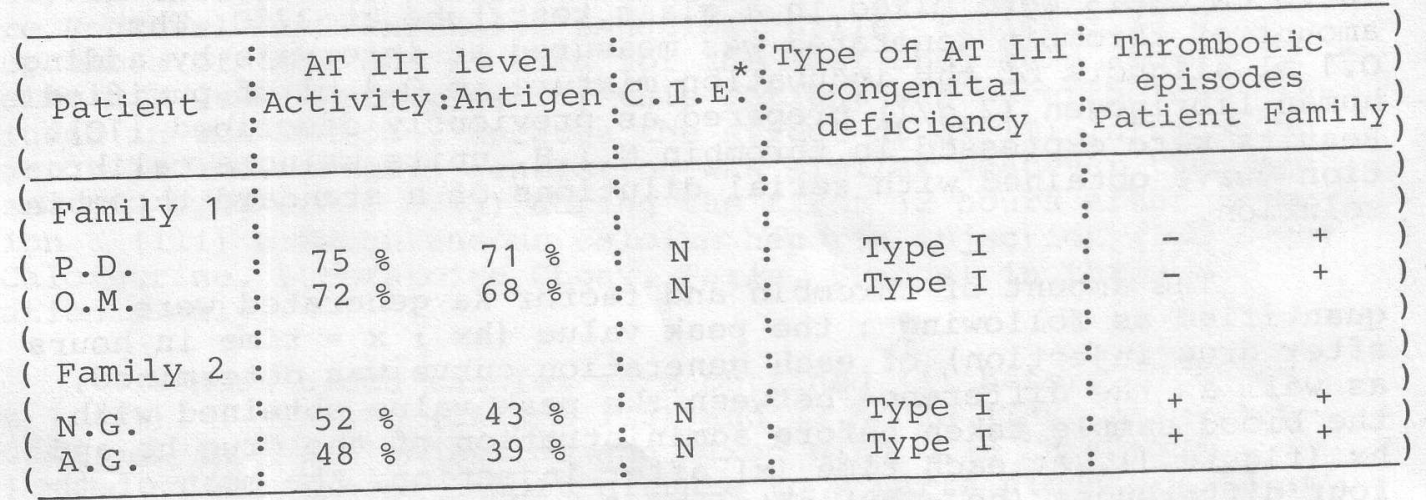

* Crossed Immuno-Electrophoresis (with or without heparin). 
Effects of each drug on prothrombin time and on K.C.C.T.

The results are summarized in table 2 . In the laboratory, the normal values of K.C.C.T. and P.T. are : K.C.C.T. $=62 \pm 8$ seconds, $\mathrm{P} . \mathrm{T} .=13 \pm 1$ seconds.

\section{TABLE 2}

EFFECT OF EACH DRUG ON P.T. AND K.C.C.T.

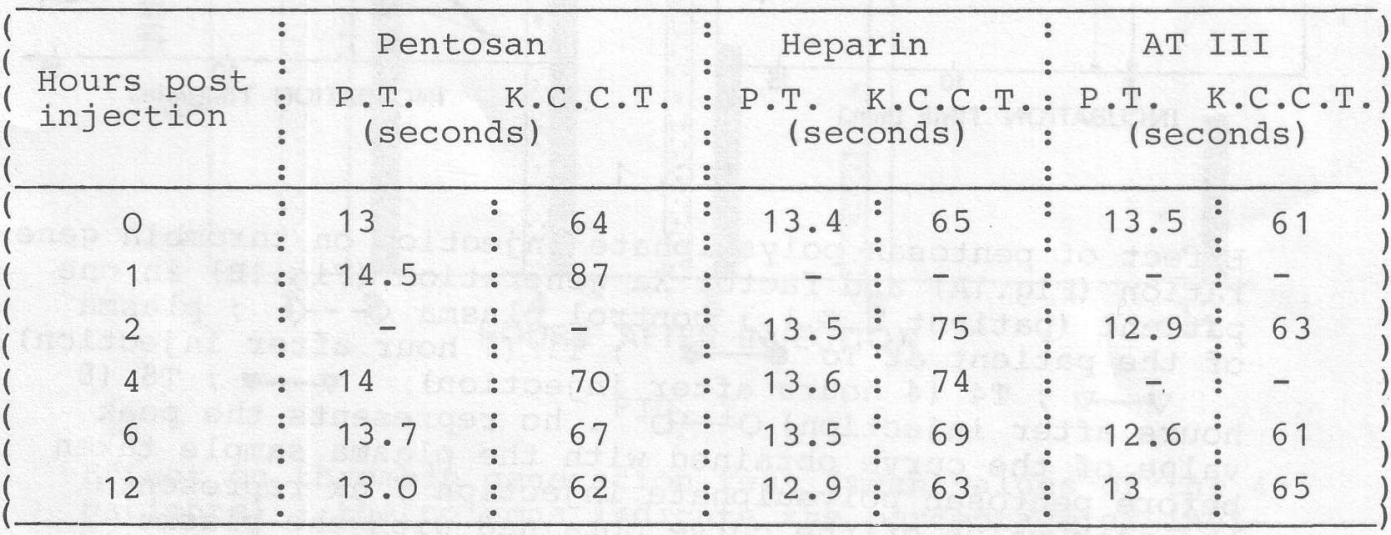

The results are the means of the values of the patients.

After AT III injection no effect on prothrombin time could be observed. After heparin injection no prolongation of the prothrombin time could be observed as the thromboplastin (Neoplastin, Laboratoire Stago, France) contained protamin. After pentosan polysulphate injection, the prolongation of prothrombin time 1 hour after injection was below 2 seconds. There was no effect on K.C.C.T. after AT III infusion. After heparin injection, there was a moderate prolongation $(75 \mathrm{sec} / 65 \mathrm{sec})$ of the K.C.C.T. two hours after injection. After pentosan polysulphate injection, there was a slightly higher prolongation of the K.C.C.T. $(87 \mathrm{sec} / 64 \mathrm{sec}) 1$ hour after injection.

\section{Effect on thrombin and factor Xa generation tests}

To illustrate the results and the method used to calculate the inhibition of thrombin and factor Xa generation, the data obtained in one patient after injection of one drug (pentosan polysulphate) are shown on figure 1. 

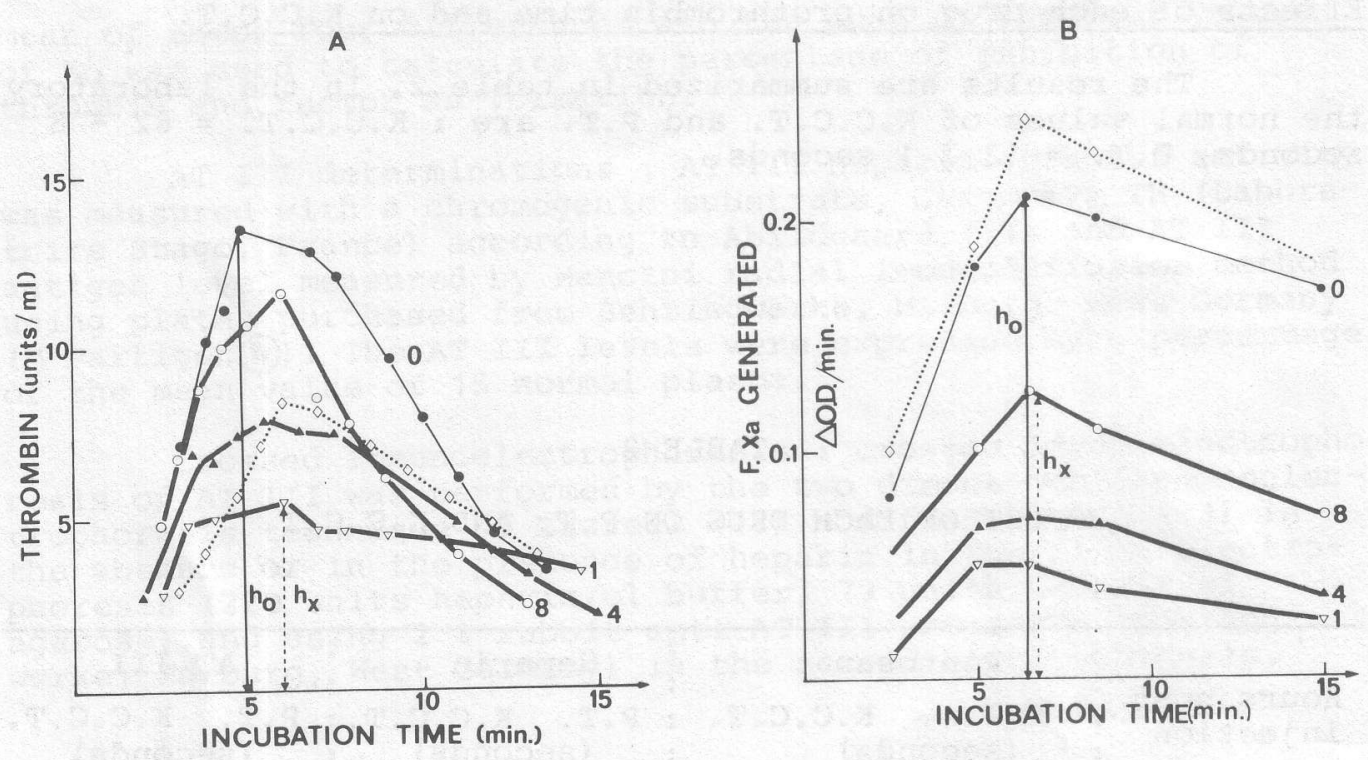

FIG. 1

Effect of pentosan polysulphate injection on thrombin generation (Fig.1A) and factor $\mathrm{Xa}$ generation (Fig.1B) in one patient (patient N.G.) : control plasma $\diamond--\diamond$; plasma of the patient at To $\longrightarrow$ T1 ( 1 hour after injection) $\nabla \rightarrow$ T4 (4 hours after injection) hours after injection) $0-0$. ho represents the peak value of the curve obtained with the plasma sample taken before pentosan polysulphate injection; hx represents the peak value of the curve obtained with the plasma sample taken $x$ hours $(x=1,4$ or 8 hours) after injection.

Effect on thrombin generation test (figure 2).

AT III infusion : as we reported before (6), the plasma of the AT III deficient patients generated nearly twice as much thrombin than normal plasma. AT III infusion inhibited the excessive thrombin generation ( $46 \%$ of inhibition at T2). This inhibition was still effective at T12 (18\% of inhibition). The maximum inhibition was the same for the three patients infused with $40 \mathrm{U} / \mathrm{kg}$ AT III as for the patient infused with $20 \mathrm{U} / \mathrm{kg} \mathrm{AT}$ III.

Heparin injection (only in three subjects) : heparin injection was followed by an inhibition of thrombin formation (71 \% of inhibition at T2) that remained important at T8 (42\%) but has subsided at T12.

Pentosan polysulphate injection : after pentosan polysulphate injection, the inhibition of thrombin generation was $62 \%$ at T1, it persisted until T8 (15\%) but there was no more effect at $\mathrm{T} 12$. 
Using a non parametric test of Kruskal and Wallis, no significative difference was found concerning the maximum effect of the three drugs.

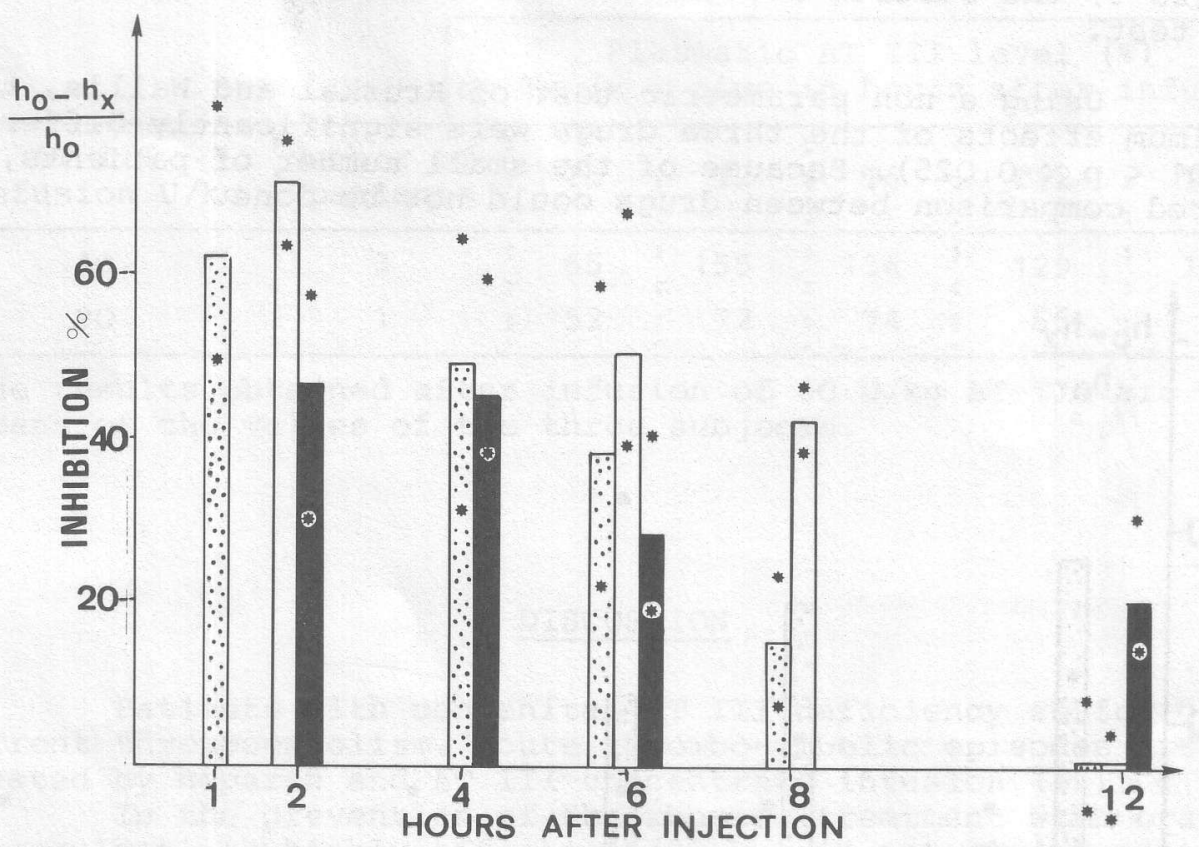

FIG. 2

Effect on thrombin generation test (mean values of the 4 patients) : the columns indicate the percentage of inhibition (ho - hx)/ho of thrombin formation after : सB.m pentosan polysulphate injection ; heparin injection :

\section{Effect on factor Xa generation test (figure 3)}

Before injection, the plasma of the patients generated the same amount of factor Xa as normal plasma did (normal subjects, $\mathrm{n}=13$, ho $=0.198 \pm 0.094 ;$ patients before injection, $\mathrm{n}=4,11$ plasmatic samples, ho $=0.221 \pm 0.015)$. on figure 3 .

The effect of the drugs on factor xa generation are shown

AT III infusion : no effect of AT III infusion on factor Xa generation test could be observed.

Heparin injection (only in three subjects) : two hours after injection there was a moderate inhibition of factor Xa generation (27\%) at $\mathrm{T} 2$ and this effect was negligible after T4. 
Pentosan polysulphate injection : the inhibition of factor $\mathrm{Xa}$ formation (57 \%) was as important as the inhibition of thrombin formation and was still significant at T6 (42\%); at T8 (20\%) the results are just at the limit of sensitivity of the test.

Using a non parametric test of Kruskal and Wallis, the maximum effects of the three drugs were significantly different maximum effects
(0.01< $<<0.025)$. Because of the small number of patients, a
paired comparison between drugs could not be done.

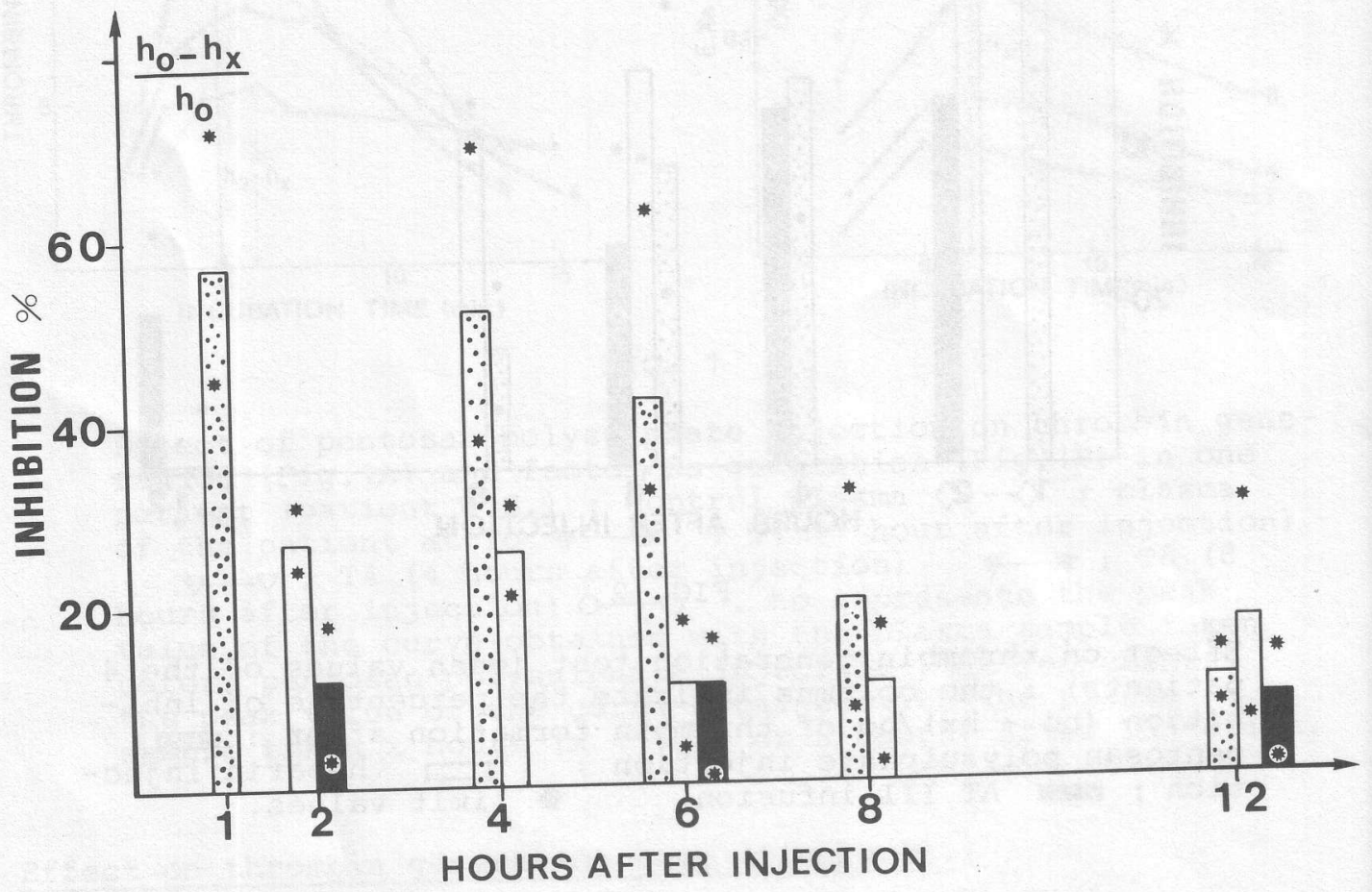

Effect on factor Xa generation test (mean values of the 4 patients) : the columns indicate the percentage of inhibition (ho - hx)/ho of factor Xa formation after : pentosan polysulphate injection ;

$\rightleftarrows$ heparin injection : AT III infusion.

AT III level

After heparin and pentosan polysulphate injection, there was no change in AT III level, while there was of course an increase of AT III level (table 3) after AT III infusion. 
TABLE 3

PLASMATIC AT III LEVEL AFTER AT III CONCENTRATE INFUSION

Plasmatic AT III level (\%) (at $\operatorname{Tx}(\mathrm{x}=$ time in hours after infusion))

\begin{tabular}{|c|c|c|c|c|c|c|c|c|c|c|c|}
\hline $\begin{array}{c}\text { AT III } \\
\text { infusion } \mathrm{U} / \mathrm{kg}\end{array}$ & $\begin{array}{l}\text { Number of } \\
\text { : patients }\end{array}$ & $\begin{array}{l}: \\
\vdots \\
\end{array}$ & To & $\begin{array}{l}: \\
\vdots \\
\end{array}$ & T2 & : & T6 & : & T12 & $:$ & T24 \\
\hline 40 & $\begin{array}{l}: \\
:\end{array}$ & : & 65 & : & 155 & : & 136 & : & 129 & : & 117 \\
\hline 20 & 1 & $\vdots$ & 52 & : & 72 & : & 74 & : & 65 & : & 68 \\
\hline
\end{tabular}

The results obtained after infusion of $40 \mathrm{U} / \mathrm{kg}$ AT III are the means of the values of the three subjects.

\section{DISCUSSION}

Patients with congenital AT III deficiency suffer of recurrent thromboembolism. Acute thrombo-embolic episodes are treated by heparin and AT III concentrate infusion (15) .

In the prevention of thrombosis, treatment with oral anticoagulant is highly effective (2) but is not always suitable (pregnancy, intestinal malabsorption, surgery...). In these circumstances, it could be theoretically interesting to use pentosan polysulphate ; this drug, as heparin, inhibits the formation of factor $\mathrm{Xa}$ and thrombin but exerts its effect by an AT III independent mechanism and appeared to be in vitro, in the absence of AT III, about twice as potent as heparin when compared on a weight basis (5).

So, we studied the effect of pentosan polysulphate injection in 4 patients with AT III congenital deficiency (type I) and compared it to the effects of AT III concentrate infusion and heparin injection. The amount of injected drugs was chosen according to the usual prophylactic posology used for example in surgery $(16,17)$. It is well known that the plasma of the AT III deficient patients generates more thrombin than normal plasma $(6,7)$. We found in this study that the intrinsic generation of factor $\mathrm{Xa}$ is normal in these patients. This is probably due to the fact that factor Xa when bound to phospholipids in the presence of factor $V$ is protected from inhibition by AT III (18, 19) and we can speculate that it must be the same for factor IXa when bound to phospholipid.

In patients with a high risk of thrombosis it could be of interest to try with a prophylactic treatment, not only to bring back to normal their excessive generation of thrombin but also to act earlier in the coagulation cascade. It is the reason why we decided to estimate the effects of the three drugs by monitoring thrombin and factor Xa generation. AT III infusion inhibits the excessive thrombin generation ( $46 \%$ inhibition at T2 after injection and still $18 \%$ inhibition at T12), but does 
not modify the factor Xa formation ; on the contrary, pentosan polysulphate has a marked effect on both thrombin (62 \% inhibition) and factor Xa generation (57\% inhibition) pentosan present at T8. Heparin injection has the same effect as put but polysulphate on thrombin generation $171 \%$ inhibition effective on impairing factor Xa generation (27\% inhibition). The more important effect of pentosan polysulphate compared to plasma is in good agreement with the result obtained in vitro in previous studies (5) but the effect on thrombin generation test is more prolonged after heparin than after pentosan polysulphate injection. The AT III infusion has no effect on the K.C.C.T.. After heparin and pentosan polysulphate injection there is a slight prolongation of the K.C.C.T.A.All the results were similar in the patients of both studied families despite slightly different levels of AT III.

The most appropriate prophylactic treatment in AT III congenital deficiency when oral anticoagulation is not suitable, is still discussed. The use of heparin does not look logical because it needs the presence of AT III to be quite effective ; moreover heparin decreases the level of plasmatic AT III (20) even when given subcutaneously (21). This is the reason why some physicians prefer the combination of subcutaneous heparin and AT III concentrates (22). However in our study, heparin alone, at AT III concentrates (22). However in ous
the doses used, has a more prolonged effect on the inhibition of
thrombin formation. Moreover since this work was completed, coutant and coll. (23) and Van Putten and coll. (24) have reported that heparin is rapidly and partially inactivated during blood sampling unless anti-platelets agents are added to the anticoagulant solution. Therefore the ability of heparin in inhibiting IIa and Xa generation reported in this paper is probably underestimated both in extent and duration. Other authors prefer to use AT III concentrates alone (25); these infusions of AT III concentrates result in a potential risk of transmitting hepatitis to patients (26). Moreover our results indicate that infusion of AT III concentrates does not inhibit factor xa formation, while pentosan polysulphate does. Theoreticallýon of thrombin formal prophylactic measure than thrombin scavenging (27) ; therefore pentosan polysulphate treatment looks like a logical and effective alternative for preventing thrombosis in AT III deficient patients. However there is as yet no study of the effect of pentosan polysulphate during pregnancy that would allow to assert its innocuity for during pregnancy that would allow to assert
the foetus. Further studies are necessary to establish the thera-
peutic range, $i . e$. to determine what dosesgive adequate thrombosis prevention without causing bleeding complications.

\section{ACKNOWLEDGMENTS}

The authors express their gratitude to Dr. Ph. DESCAMPS for advice and help with the statistical analysis and to Mrs M.L. FOURNEAUX and L. NIVEAU for preparation of the manuscript. 


\section{REFERENCES}

1. EGEBERG, O. Inherited antithrombin deficiency causing thrombophilia, Thromb. Diath. haemorrh. 13, 516-530, 1965.

2. THALER, E. and LECHNER, K. Antithrombin III deficiency and thrombo-embolism. In : Clinics in Haematology. C.R.M. Prentice (Ed.) London: Saunders, Vol. 10, $\mathrm{n}^{\circ} 2,1981, \mathrm{pp} .369-390$.

3. SORIA, C., SORIA, J., RYCKEWAERT, J.J., HOLMER, E. and CAEN, J. Anticoagulant activities of a pentosan polysulphate : comparison with standard heparin and a fraction of low molecular weight heparin. Thromb. Res. 19, 455-463, 1980.

4. VINAZZER, H., HASS, S. and STEMBERGER, A. Influence on the clotting mechanism of sodium pentosan polysulphate (SP 54) in comparison to commercial beef lung sodium heparin. Thromb. Res. $20,57-68,1980$.

5. FISCHER, A.M., BARROWCLIFFE, T.W. and THOMAS, D.P. A comparison of pentosan polysulphate (SP 54) and heparin. I : Mechanism of action on blood coagulation. Thromb. Haemost. 47, $104-108,1982$.

6. JOSSO, F., AUROUSSEAU, M.H., FISCHER, A.M., DAUTZENBERG, M.D. and BEGUIN, S. Hereditary antithrombin III deficiency. Evidence of increased thrombin formation in the early stage of haemostasis (abstract). Thromb. Haemost. 37, 75, 1977.

7. BOYER, C. , WOLF, M. , LAVERGNE, J.M. and LARRIEU, M.J. Thrombin generation and formation of thrombin-antithrombin III complexes in congenital antithrombin III deficiency. Thromb. Res. 20, 207-218, 1980 .

8. FISCHER, A.M., MERTON, R.E., MARSH, N.A., WILLIAMS, S., GAFFNEY, P.J., BARROWCLIFFE, T.W. and THOMAS, D.P. A comparison of pentosan polysulphate and heparin. II : Effects of subcutaneous injection. Thromb. Haemost. 47, 109-113, 1982.

9. JOSSO, F. and PROU-WARTELLE, O. Tests de I'hémostase. In : Techniques en hématologie. D. Alagille, J. Colombani, J. Dausset, J.M. Fine and F. Josso (Eds.) Paris: Flammarion, 1972, pp. 141-191.

10. JOSSO, F., RIO, Y. and BEGUIN, S. A new variant of human prothrombin : prothrombin Metz, demonstration in a family showing double heterozygosity for congenital hypoprothrombinemia and dysprothrombinemia. Haemostasis, 12, 309-316, 1982.

11. ABILDGAARD, U., LIE, M. and $\varnothing D E G A R D, O . R$. Antithrombin (heparin cofactor) assay with new chromogenic substrates (S-2238 and chromozym TH). Thromb. Res. 2, 549-553, 1977.

12. LAURELL, C.B. Antigen-antibody crossed electrophoresis. Anal. Biochem. 10, 358-361, 1965. 
13. SAS, G., PEPPER, D.S. and CASH, J.D. Plasma and serum antithrombin III : Differenciation by crossed immunoelectrophoresis. Thromb. Res. 6, 87-91, 1975.

14. BENTATA-PESSAYRE, M. , AUROUSSEAU, M.H., JOSSO, F. et DELZANT, G. Maladie thrombo-embolique familiale et déficit en antithrombine III. Ann. Med. Interne, 131, 378-382, 1980.

15. HELLGREN, M., TENGBORN, L. and ABILDGAARD, U. Pregnancy in women with congenital antithrombin III deficiency : Experience of treatment with heparin and antithrombin. Gynecol. obstet. Invest. 14, 127-141, 1982 .

16. BERGQVIST, D., EFSING, H.O., HALLBOOK, T. and LINDBLAD, B. Prevention of post-operative thrombo-embolic complications : A prospective comparison between Dextran 70, Dihydroergotamin Heparin and a sulphated polysaccharid. Acta Chir. Scand. $146,559-568,1980$.

17. KAKKAR, V.V., FIELD, E.S., NICOLAIDES, A.N. and YIU, L.T. Low doses of heparin in prevention of deep vein thrombosis. Lancet, $2,669-671,1971$.

18. JOSSO, F. and BEGUIN, S. Changes in the antithrombin III activity at the interface plasma-phospholipids (abstract). Thromb. Haemost. $46,285,1981$.

19. MARCINIAK, E. Factor Xa inactivation by antithrombin III : Evidence for biological stabilization of factor Xa by factor V-phospholipid complex. Brit. J. Haemat. 24, 391-400, 1973.

20. MARCINIAK, E. and GOCKERMAN, J.P. Heparin-induced decrease in circulating antithrombin III. Lancet, $\underline{2}, 581-584,1977$.

21. BOLWERK, C.J.M., HENNY C.P., BRULLER, H.R. and TEN CATE, J. W. Hereditary AT III deficiency and heparin. Thromb. Res. $28,689-690,1982$.

22. BRANDT, $P$. Observations during the treatment of antithrombin III deficient women with heparin and antithrombin concentrate during pregnancy, parturition and abortion. Thromb. Res. $22,15-20,1981$.

23. CONTANT, G., GOUAULT-HEILMANN, M. and MARTINOLI, J.L. Heparin inactivation during blood storage; its prevention by blood collection in citric acid, theophylline, adenosine, dipyridamole-C.T.A.D. mixture. Thromb. Res. 31, 365-374, 1983.

24. PUTTEN, J.J. van, RUIT, M. van de, BEUNIS, M. and HEMKER, H.C. Heparin neutralization during collection and processing of blood inhibited by pyridoxal $5^{\prime}$-phosphate. Haemostasis 14, 253-261, 1984. 
25. MANNUCCI, P.M., BOYER, C., WOLF, M., TRIPOLI, A. and LARRIEU, M.J. Treatment of congenital antithrombin III deficiency with concentrates. Brit. J. Haemat. 50, 531-535, 1982.

26. TABOR, E., MURANO, G., SNOY, P. and GERETY, R.J. Inactivation of hepatitis B virus by heat in antithrombin III stabilized with citrate. Thromb. Res. 22, 232-238, 1981.

27. KAKKAR, V.V. Prevention of venous thromboembolism. In : Haemostasis and Thrombosis. A.L. Bloom and D.P. Thomas (Eds.) Edinburgh : Churchill Livingstone, 1981, pp. 669-683. 